\title{
Posztoperatív vertigo vizsgálata stapedotomián és stapedectomián átesett betegeknél
}

\author{
Harmat Kinga dr. ${ }^{1}$. Thurén Gergely dr. ${ }^{2}$. Simon László dr. ${ }^{3}$ \\ Nepp Nelli dr. ${ }^{1}$ - Németh Adrienn dr. ${ }^{1}$ \\ Gerlinger Imre dr. ${ }^{1}$ - Bakó Péter dr. ${ }^{1}$ \\ ${ }^{1}$ Pécsi Tudományegyetem, Általános Orvostudományi Kar, Klinikai Központ, \\ Fül-Orr-Gégészeti és Fej-Nyaksebészeti Klinika, Pécs \\ ${ }^{2}$ Markusovszky Egyetemi Oktatókórház, Arc-, Állcsont- és Szájsebészeti Osztály, Szombathely \\ ${ }^{3}$ Semmelweis Egyetem, Általános Orvostudományi Kar, Anatómiai, Szövet- és Fejlődéstani Intézet, Budapest
}

\begin{abstract}
Bevezetés és célkitüzés: Az otosclerosisban szenvedők vezetéses halláscsökkenésének hátterében legnagyobbrészt a kengyel (stapes) talpának a környezetéhez való fixációja áll. Az elváltozás terápiája általában mútéti, amelynek során a stapest részlegesen (stapedotomia) vagy teljesen (stapedectomia) eltávolítjuk. Stapedotomia során a stapes talpán lézer és mikrofúró segítségével egy 0,8 mm átmérőjü nyílást készítünk, stapedectomia során viszont a teljes talpat távolítjuk el, majd hallócsont-láncolati rekonstrukciót végzünk. A korai posztoperatív idôszakban gyakran jelentkezik átmenetileg szédülés, amely a lábadozást nagyban befolyásolja.

Módszer: A Pécsi Tudományegyetem, Klinikai Központ, Fül-Orr-Gégészeti és Fej-Nyaksebészeti Klinikán 2010. február 1. és 2012. március 15. között mútéti megoldásként stapedotomiát, valamint stapedectomiát is alkalmaztunk. Vizsgálatunk a két különböző módszerrel operált betegek posztoperatív szédülésének összehasonlítására irányult. Feltételezésünk az volt, hogy a stapedotomia kapcsán készített kisebb nyílás kisebb traumát okoz a belső fülben, így enyhébb fokú és rövidebb időtartamú szédülés jelentkezik a posztoperatív időszakban. A betegek szubjektív szédülésérzetét retrospektív kérdőíves módszerrel mértük fel, emellett statikus poszturográfiás vizsgálatot is végeztünk.

Eredmények: A kérdőíves felmérés alapján az első posztoperatív napon a stapedotomiával operált betegek közül szignifikánsan kevesebben és enyhébb mértékben éltek meg szédülést. A későbbi posztoperatív időszakra vonatkozóan azonban már nem találtunk szignifikáns különbséget a két mútéttípus között az adott válaszok alapján. Az objektív poszturográfiás vizsgálatok alapján nem találtunk szignifikáns különbséget a betegek stabilitásában a két mútéti csoport között. A kérdőíven adott válaszok, valamint a poszturográfiás vizsgálat eredményei nem mutattak összefüggést, a szédülés megélésének mértékét a poszturográfiás vizsgálatok eredményei nem támasztották alá.

Következtetés: A stapesmútétek kapcsán jelentkező posztoperatív szédülés kialakulásában feltehetőleg számos faktor játszik szerepet, amelyet a mútéti típus lényegesen nem befolyásol.
\end{abstract}

Orv Hetil. 2017; 158(38): 1503-1511.

Kulcsszavak: otosclerosis, posztoperatív komplikáció, stapedotomia, stapedectomia, vertigo

\section{Comparative evaluation of vertigo in patients after stapedotomy and stapedectomy}

Introduction and aim: The reason of gradually developing conductive hearing loss in otosclerotic patients is the ossification of the stapes footplate to the surrounding bony structures and the therapy of stapes fixation is mainly surgical. In stapedotomy the footplate of the stapes is fenestrated with laser and microdrill in a diameter of $0.8 \mathrm{~mm}$, whereas in stapedectomy there is complete removal of the footplate followed by the reconstruction of the ossicular chain. In the early postoperative period, temporary vertigo is frequently recorded which significantly influences the recovery.

Method: In the Department of Otorhinolaryngology, University of Pécs both stapedectomy and stapedotomy were performed on a daily basis between 01.02.2010 and 15.03.2012. Our study focused on comparing the degree of postoperative vertigo after the two types of surgery. We hypothesized that the smaller fenestration of the stapes foot- 
plate during stapedotomy limits exposure to the inner ear reducing the severity of dizziness. Vertigo was evaluated subjectively with a retrospective questionnaire and objectively with static posturography.

Results: On the lst postoperative day, significantly fewer patients reported vertigo in the stapedotomy group and with significantly lower intensity. Results of the questionnaire regarding the later postoperative period showed no significant differences between the groups. Based on the analysis of the posturography test results, no significant difference was detected between the postoperative stability of the two groups. Results of the questionnaire and the posturography showed no correlation. Posturography test results did not confirm the presence of subjective vertigo. Conclusion: Many factors may play a role in the development of vertigo after stapes surgery, but the type of intervention does not influence it.

Keywords: otosclerosis, postoperative complications, stapes mobilization, stapes surgery, vertigo

Harmat K, Thurén G, Simon L, Nepp N, Németh A, Gerlinger I, Bakó P. [Comparative evaluation of vertigo in patients after stapedotomy and stapedectomy]. Orv Hetil. 2017; 158(38): 1503-1511.

(Beérkezett: 2017. július 4.; elfogadva: 2017. augusztus 10.)

\begin{abstract}
Rövidítések
API = (antero-posterior integral) előre-hátra irányú súlypontingadozás integrálértéke; $\mathrm{CBCT}=($ cone-beam $\mathrm{CT})$ conebeam komputertomográfia; $\mathrm{CDP}=($ computerized dynamic posturography) számítógépes dinamikus poszturográfia; $\mathrm{CI}=$ (confidence interval) konfidenciaintervallum; $\mathrm{CT}=($ computer tomography) komputertomográfia; LRI $=($ left-right integral $)$ oldalirányú súlypontingadozás integrálértéke; OR = (odds ratio) esélyhányados; RTI = (radier integral) radiális súlypontingadozás integrálértéke; $\mathrm{SDE}=$ stapedectomia; $\mathrm{SDO}=$ stapedotomia; VEMP $=$ (vestibular evoked myogenic potencials) vestibularisan kiváltott myogen potenciálok; vHIT $=$ (video head-impulse test) video fej-impulzus teszt; VOG $=$ (videooculography) video-okulográfia
\end{abstract}

Az otosclerosis a belső fül csontos tokjának kóros csontátépüléssel járó megbetegedése. Első tünete általában lassan progrediáló, egy- vagy kétoldali vezetéses hallásromlás, amelyhez esetenként fülzúgás is társul. Vestibularis tünetek ritkábban jelentkeznek. Az otoscleroticus góc leggyakoribb előfordulási helye az oticus capsulában a cochlea és a vestibulum között, közvetlenül a stapestalp előtt van (fissula ante-fenestram). Valószínúleg ez a szoros anatómiai viszony a stapestalp és a vestibulum között tehető felelőssé a vestibularis tünetek jelentkezéséért otosclerosisban [1]. Gros és mtsai szerint az otoscleroticus betegek 20\%-a számol be szédüléses panaszokról [2]. Vestibularis tünetek okaként a vestibularis szervek otoscleroticus érintettségét jelölte meg Sando [3]. $\mathrm{Pa}$ parella és mtsai a vertigo megjelenését a perilympha biokémiai összetételének megváltozásával magyarázták [4]. A vestibularis tünet előfordulhat folyamatosan fennálló panaszként, visszatérő szédülésként, illetve leírtak fejhelyzethez kötött szédülést is. Crossland és mtsai szerint benignus paroxysmalis vertigo olyan betegekben fordul elő, akiknek igen elörehaladott az otosclerosisuk [5]. Hayashi és mtsai szignifikánsan magas arányban cupularis depozitumot talált otoscleroticus betegek sziklacsontjában, viszont nem találtak összefüggést a cupularis depo- zitumok megléte, illetve a vestibularis tünetek mértéke között [6]. Paparella és mtsai szerint lehet összefüggés a vertigóval járó, illetve vertigo nélküli endolymphaticus hydrops és az előrehaladott otosclerosis között [7]. A szédülés hátterében álló mechanizmusok a következők lehetnek: fizikális vagy funkcionális obstrukció az aqueductus vestibuliban, a perilymphában történő biokémiai változások, illetve a vestibularis ideg károsodása [8-10]. Morales-Garcia szerint a vestibularis tünetek cochlearis érintettség mellett is előfordulnak [11].

A vestibularis tünetek vizsgálata több módszerrel is lehetséges. Özmen dinamikus poszturográfiával nyert eredményei alapján közvetlenül stapedotomiát követően a betegek $82 \%$-a szédült különböző mértékben, egy hét elteltével viszont már nem mutatott a vizsgálat eltérést [12]. Karaca perforátorral és lézerrel végzett stapedotomiák után videonystagmographiát végzett hat órával a mútétet követően, valamint a második posztoperatív napon. A spontán és pozicionális nystagmus regisztrálásával nem találtak különbséget a vestibularis következményekben a különböző mútéti típusok között [13]. Hirvonen stapesmútétet követően egy órán belül végzett nystagmographiát. A betegek közel felénél volt nystagmus kimutatható, szédülést a betegek $45 \%$-a jelzett a mútét napján. A nystagmus jelenléte nem korrelált a szédüléses panaszokkal [14].

Stapesfixáció esetén két mútéti módszer terjedt el a sebészi gyakorlatban: a stapedotomia (SDO) és a stapedectomia (SDE). Mindkét mútéti megoldás jó audiológiai eredménnyel jár [15-17]. Klinikánk azon ritka intézetek egyike, ahol egy időszakban mindkét mûtéttípust rutinszerúen végeztük, így lehetőség nyílt a mútétek következményeinek összehasonlítására [18-20].

Tanulmányunkban stapedotomián, valamint stapedectomián átesett betegek posztoperatív szédülését vizsgáltuk egy szubjektív jellegú vizsgálatnak tekinthető retrospektív kérdőív, valamint objektív módszernek tekinthető statikus poszturográfia segítségével. 


\section{Betegek és módszer}

Klinikai tanulmányunkban 2010. február 1. és 2012. március 15 . között operált 24 , stapesmütéten átesett beteg adatait dolgoztuk fel. 12-12 esetben stapedectomia, illetve stapedotomia volt az alkalmazott mútéti típus. A betegek demográfiai adatait az 1. táblázat mutatja be

1. táblázat |A vizsgált betegek adatai

\begin{tabular}{llllll}
\hline Mútéttípus & Nö & Férfi & Átlagéletkor & Átlagmagasság & $\begin{array}{l}\text { Átlagos } \\
\text { testtömeg }\end{array}$ \\
\hline $\begin{array}{l}\text { SDO } \\
(\mathrm{n}=12)\end{array}$ & $\begin{array}{l}8 \\
(67 \%)\end{array}$ & $\begin{array}{l}4 \\
(33 \%)\end{array}$ & 49,9 év & $166,80 \mathrm{~cm}$ & $67,60 \mathrm{~kg}$ \\
$\begin{array}{l}\mathrm{SDE} \\
(\mathrm{n}=12)\end{array}$ & $\begin{array}{l}11 \\
(92 \%)\end{array}$ & $\begin{array}{l}1 \\
(8 \%)\end{array}$ & 42,9 év & $165,08 \mathrm{~cm}$ & $66,75 \mathrm{~kg}$ \\
\hline
\end{tabular}

\section{Mütéti leirás}

Stapedectomia során a kengyel szuperstruktúrája mellett a teljes talp is eltávolításra került, így az ovális ablak egésze szabaddá vált. Ezt követóen az ovális ablakot a temporalis izom felszínéről vett fasciával lezártuk, majd a halántékcsont corticalis részéből készített csontcolumellával rekonstruáltuk a hallócsontláncolatot (1. ábra).

Stapedotomia során a stapes-szuperstruktúra eltávolítását követően a stapes talpán 0,6-0,8 mm átmérőjü nyílást készítettünk. A hallócsontláncolat helyreállítása ilyenkor különböző anyagokból készült protézis, úgynevezett piston alkalmazásával történik. A piston belső fül felőli része a stapedotomiás nyílásba kerül, míg a másik végén lévő hurok az incus hosszú szárán kerül rögzítésre. A vizsgálatunkban részt vevő betegeinknél nikkel-titánium ötvözet és fluoroplasztik kombinációjából készült Nitinol-pistont (Ghyrus Ltd., Németország) alkalmaztunk. A piston hurka hőmemória-effektussal rendelkezik. Nyitott formában kerül az incus szárára és ezt követően KTP-lézernyalábbal (1 W, egy-két lövés) aktiválva a memóriafunkciót, rászorul az incusra. A piston behelyezése után fasciadarabokat helyeztünk a nyílás köré [19, 20].

\section{Vizsgálati módszerek}

Betegeink szédülését kétféle - egy szubjektív és egy objektív - módszerrel vizsgáltuk.

\section{Retrospektín kérdöíves módszer}

A betegek a mútét után minimum 90 nappal retrospektíven egy kérdőívet töltöttek ki. Az általunk összeállított kérdőív 30 kérdést tartalmazott a preoperatív, valamint a korai és a késői posztoperatív időszakra vonatkozóan. A vizuális analóg skálán 1 -es érték jelentette a legenyhébb, 5-ös érték a legerősebb szédülést, míg a 0 a szédülés hiányát. A kérdőív első része (első-harmadik kérdés) a pre-

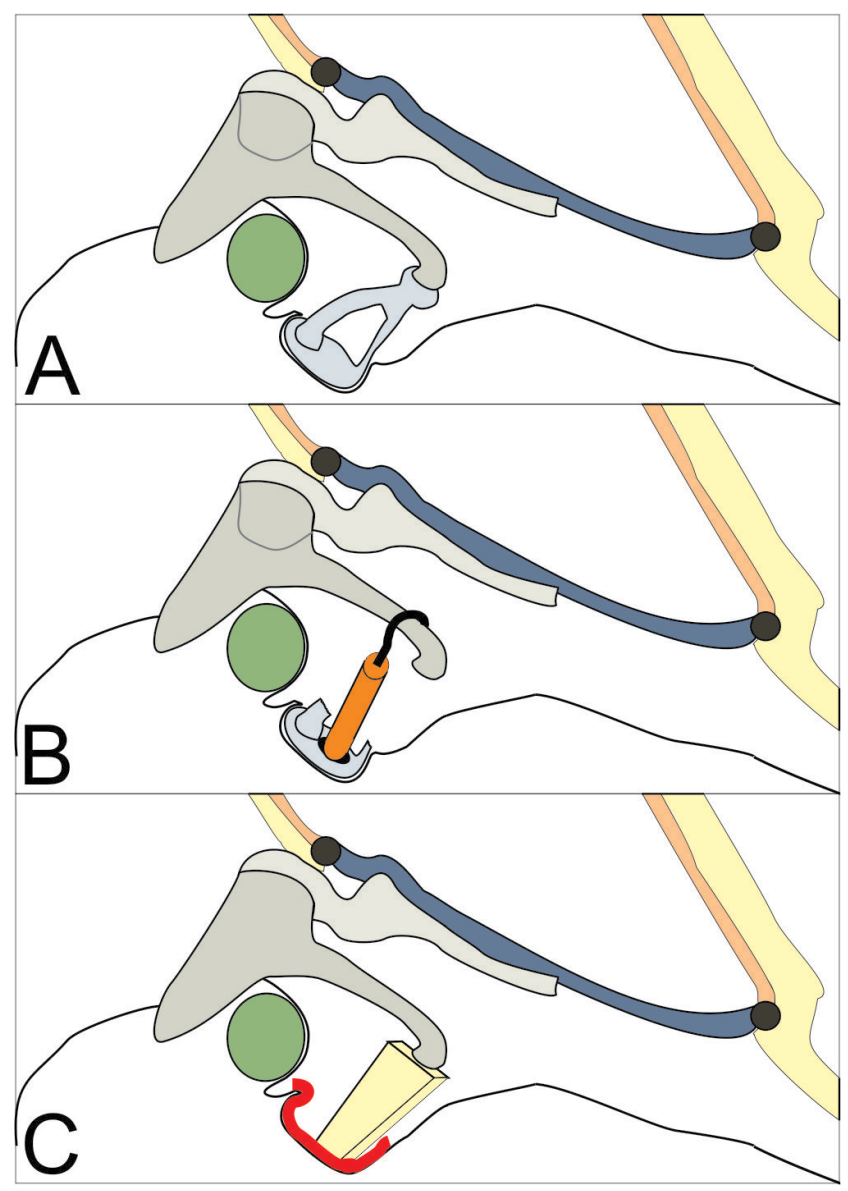

1. ábra

A: Normális középfül-anatómia a dobhártyával (sötétkék), valamint a hallócsontokkal (kalapács vajszínű, incus világosbarna, stapes világoskék). B: Stapedotomia során a stapes talpán nyílást ejtünk, majd a hallócsontláncolatot egy protézissel (narancssárga) állítjuk helyre. C: Stapedectomia kapcsán a teljes stapestalp eltávolításra kerül, az ovális ablakot temporalis izom bőnyéjével (piros) fedjük, majd a hallócsontláncolatot autológ csontcolumellával (citromsárga) állítjuk helyre

operatív időszakban esetlegesen észlelt szédüléssel kapcsolatos kérdéseket tartalmazott. A további kérdések a posztoperatív időszakra vonatkoztak. A kérdőív megszerkesztésekor nagy hangsúlyt fektettünk arra, hogy a beteg számára fontos hétköznapi funkciókat mennyire tudta jól ellátni a mütét előtt, illetve mennyivel javultak ugyanezen funkciók a mütétet követően, azaz mikor tudtak újra teljes életet élni. Az erre vonatkozó kérdéseket kérdőívünk utolsó 10 kérdése tartalmazta. A kérdőívet az 1. melléklet tartalmazza.

\section{Statikus poszturográfia}

A posztoperatív szédülés objektív felmérésére statikus poszturográfiát használtunk. A módszer különböző pozíciókban álló személy súlypontjának elmozdulását vizsgálja egy bizonyos időtartam alatt. A vizsgálandó személy egy lapos platformon áll, és egy, a szemmagasságában elhelyezkedő, tőle egy méterre lévő pontot fixál. 


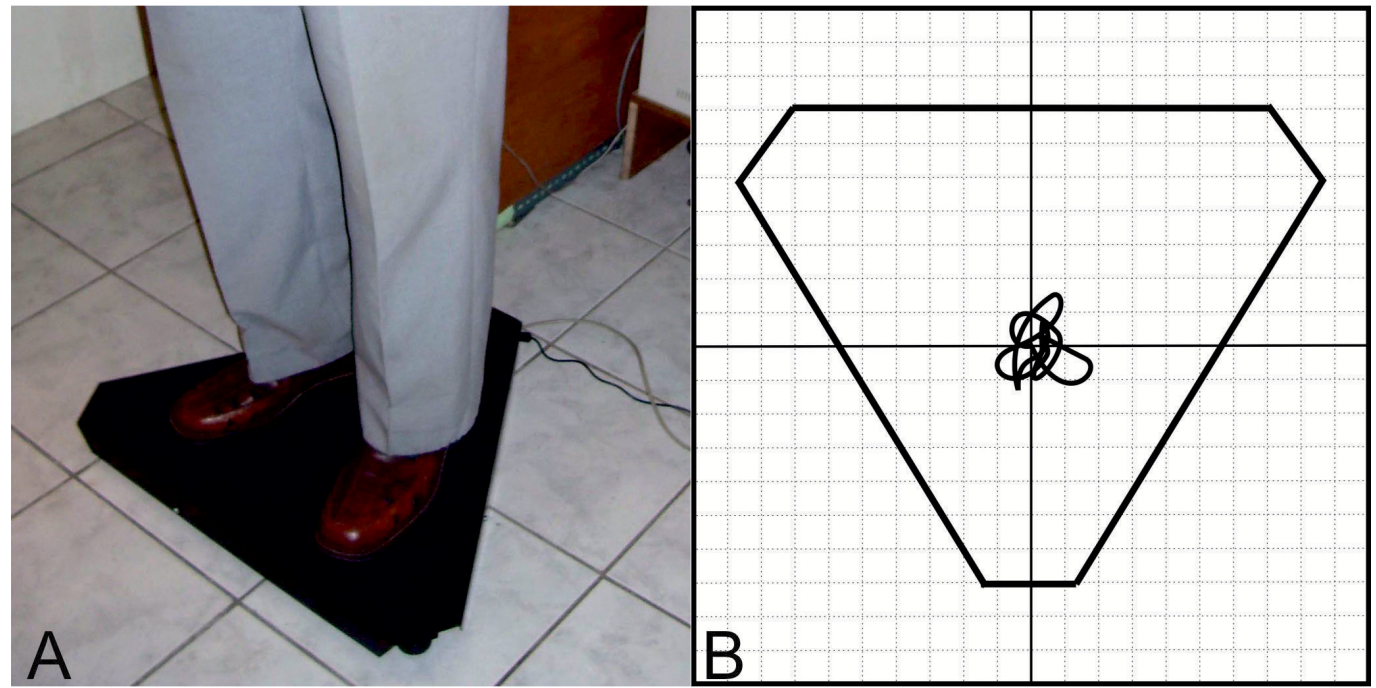

2. ábra

| A poszturográfiás platform (A) és sematikus rajza (B). A vékony fekete vonal a beteg súlypontjának elmozdulását jelöli a vizsgálat 20 másodperce alatt

Eközben a platform érzékeli a test kilengéseit, és egy szoftver segítségével diagramot készít (2. ábra). Vizsgálatunk során a betegeknek négy különböző pozícióban 20 másodpercig kellett a platformon megállni: I.: terpeszállásban, nyitott szemmel; II.: terpeszállásban, csukott szemmel; III.: összezárt lábakkal, nyitott szemmel; IV.: összezárt lábakkal, csukott szemmel (Romberg-helyzet).

A vizsgálatot a mütét előtt, valamint a posztoperatív második és harmadik napon végeztük el, illetve egy késői posztoperatív vizsgálatra (átlag 275 nap után) is sor került. A poszturográfiával kapott eredményeket egy szoftver feldolgozta és meghatározta a betegek kilengéseinek során összesen megtett utat. Az eredményekből három különböző irányú, dimenzió nélküli számot generált: oldalirányú (left-right integral - LRI), előre-hátra irányú (antero-posterior integral - API) és radiális irányú (radier integral - RTI) súlypontingadozás integrálértékét. A magasabb érték nagyobb kilengést jelentett.

A módszert egy példán keresztül mutatjuk be a könynyebb megértés céljából. A 3. ábra egy stapedectomián

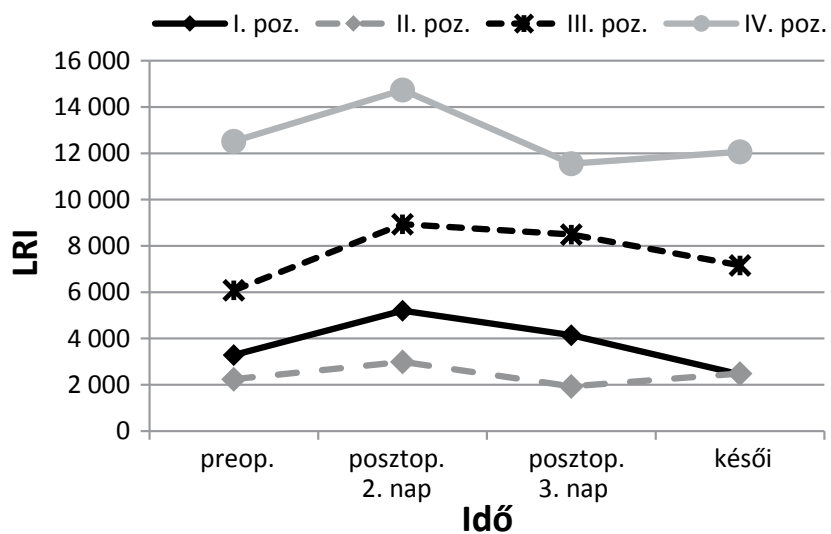

3. ábra

A poszturográfiás vizsgálat LRI-értékeinek alakulása a különböző pozíciókban a négy vizsgált időpontban. A késői posztoperatív vizsgálat jelen példában a 165 . napon történt átesett beteg oldalirányú ingadozásának integrálértékeit (LRI) mutatja az eltelt napok függvényében a négy nehézségi pozícióban. A kezdeti mérés a mütét előtti napon készült, majd a poszturográfiás vizsgálatot megismételtük a második, illetve a harmadik posztoperatív napon, majd egy késői posztoperatív időpontban, ez jelen esetben a posztoperatív 165. nap volt. Az ábrán látható, hogy mind a négy pozícióban az eredeti értékhez képest a posztoperatív második napon kis emelkedés volt tapasztalható, amely mérséklődött a harmadik posztoperatív napra. A késői posztoperatív értékek minimálisan tértek el a mütét előtti értékektől.

A kérdőívek kiértékelése IBM SSPS statistics 20 programmal történt. A statisztikai módszerek közül Studentféle t-próbát, Fisher's egzakt tesztet, Mann-Whitneytesztet alkalmaztunk. Az esélyhányadost (OR) 95\%-os konfidenciaintervallummal (CI) határoztuk meg.

\section{Eredmények}

\section{A kérdöives felmérés eredményei}

Preoperatív szédülést a 12 , stapedotomián átesett betegből 4 (33\%), míg a 12, stapedectomiával operált beteg közül $3(25 \%)$ jelzett (1. kérdés). A két csoport között szignifikáns különbség nem volt $(\mathrm{p}=0,65, \mathrm{p}>0,05)$.

A mútétet követő első napon az SDO-n átesettek közül 5 beteg (42\%), míg az SDE-n átesett betegekből 11 en (92\%) jeleztek szédülést (4. kérdés). Ez a különbség szignifikánsnak bizonyult (OR: 7,0; CI: 1,04-46,95). Fontos azonban megfigyelni az igen nagy szórási intervallumot, ami valószínúleg a kis betegszámmal magyarázható. $\mathrm{Az}$ SDO-n átesett betegek esetében az első posztoperatív napon jelzett szédülés erősségének mértéke átlag 1,416 volt, míg az SDE-n átesettnél ez az átlagérték 3,16 volt, amely statisztikailag szignifikáns különbségnek bizonyult (6. kérdés; $\mathrm{p}=0,042, \mathrm{p}<0,05)$. A két 
1. melléklet | Kérdőív

1. A mütétet megelőzően voltak-e szédüléses panaszai? Igen. Nem.

2. Amennyiben igen, milyen jellegüek voltak ezek? Forgó jellegű szédülés. Bizonytalanságérzés. Egyensúlyzavar. Ájulással kísért.

3. Milyen erősek voltak ezek a panaszok? $\begin{array}{llllll}0 & 1 & 2 & 3 & 4 & 5\end{array}$

4. A mútétet követő első napon voltak-e szédüléses panaszai? Igen. Nem.

5. Amennyiben igen, milyen jellegűek voltak ezek? Forgó jellegű szédülés. Bizonytalanságérzés. Egyensúlyzavar. Ájulással kísért.

6. Milyen erôsek voltak ezek a panaszok? $\begin{array}{llllll}0 & 1 & 2 & 3 & 4 & 5\end{array}$

7. Jártak-e panaszai a következőkkel? Hányinger. Hányás

8. Tudott-e egyedül közlekedni? Igen. Nem.

9. A mútétet követő második napon voltak-e szédüléses panaszai? Igen. Nem.

10. Amennyiben igen, milyen jellegúek voltak ezek? Forgó jellegű szédülés. Bizonytalanságérzés. Egyensúlyzavar. Ájulással kísért.

11. Milyen erősek voltak ezek a panaszok? $\begin{array}{llllll}0 & 1 & 2 & 3 & 4 & 5\end{array}$

12. Jártak-e panaszai a következókkel? Hányinger. Hányás.

13. Tudott-e egyedül közlekedni? Igen. Nem.

14. A mútétet követő harmadik napon voltak-e szédüléses panaszai? Igen. Nem.

15. Amennyiben igen, milyen jellegúek voltak ezek? Forgó jellegű szédülés. Bizonytalanságérzés. Egyensúlyzavar. Ájulással kísért.

16. Milyen erôsek voltak ezek a panaszok? $\begin{array}{llllll}0 & 1 & 2 & 3 & 4 & 5\end{array}$

\section{Jártak-e panaszai a következőkkel?} Hányinger. Hányás.
18. Tudott-e egyedül közlekedni? Igen. Nem.

19. A mútétet követően meddig álltak még fenn a panaszai? 4-6 nap. 7-10 nap. Tovább, körülbelül ... nap.

20. A mútétet követően mikor állt újra munkába? 1 héten belül.

1-2 hét között, körülbelül ... nap.

2-3 hét között: körülbelül ... nap.

Három héten túl, körülbelül ... nap.

21. A műtétet követően mikor tudott először jármúvet vezetni?

1 héten belül.

1-2 hét között, körülbelül ... nap.

2-3 hét között: körülbelül ... nap.

3 héten túl, körülbelül .... nap.

Nem vezetek.

22. A mútétet követően mikor tudott először sportolni? 1-2 hét között, körülbelül ... nap.

2-3 hét között: körülbelül ... nap.

3-4 hét között, körülbelül ... nap.

4 héten túl, körülbelül ... nap.

Nem sportolok.

23. A mútétet követően kellett-e hányinger ellen gyógyszert bevennie?

Igen. Nem.

24. Ha igen, mikor kellett a műtétet követően utoljára hányinger ellen gyógyszert bevennie?

1. nap. 2. nap. 3. nap. 4-7. nap.

1-2 hét között. 2-3 hét között. 3-4 hét között.

4 héten túl, körülbelül ... nap.

25. A mütétet követően kellett-e szédülés ellen gyógyszert bevennie?

Igen. Nem.

26. Ha igen, mikor kellett a mútétet követően utoljára szédülés ellen gyógyszert bevennie?

1. nap. 2. nap. 3. nap. 4-7. nap.

1-2 hét között. 2-3 hét között. 3-4 hét között. 4 héten túl, körülbelül ... nap.

27. Jelenleg vannak-e még megmaradt szédüléses panaszai? Igen. Nem.

28. Amennyiben igen, milyen jellegüek ezek? Forgó jellegű szédülés. Bizonytalanságérzés. Egyensúlyzavar. Ájulással kísért.

29. Milyen erősek ezek a panaszok?

$\begin{array}{llllll}0 & 1 & 2 & 3 & 4 & 5\end{array}$

30. Járnak-e panaszai a következókkel?

Hányinger. Hányás. 
2. táblázat | Szubjektív kérdőív eredményei - I. (A szédülés súlyosságánál az l-es érték jelentette a legenyhébb, az 5-ös érték a legerősebb szédülést, míg 0 a szédülés hiányát)

\begin{tabular}{|c|c|c|c|c|c|c|}
\hline & $\begin{array}{l}\text { Preoperatíve szédül } \\
\text { (fó) }\end{array}$ & $\begin{array}{l}\text { Első nap szédül } \\
\text { (fó) }\end{array}$ & $\begin{array}{l}\text { Első nap súlyosság } \\
(0-5)\end{array}$ & $\begin{array}{l}\text { Első nap önállóan } \\
\text { jár (fő) }\end{array}$ & $\begin{array}{l}\text { Második nap szédül } \\
\text { (fó) }\end{array}$ & $\begin{array}{l}\text { Második nap } \\
\text { önállóan jár (fó) }\end{array}$ \\
\hline $\begin{array}{l}\text { SDO } \\
(\mathrm{n}=12)\end{array}$ & $4(33 \%)$ & $5(42 \%)$ & 1,416 & $8(67 \%)$ & $6(50 \%)$ & $9(75 \%)$ \\
\hline $\begin{array}{l}\text { SDE } \\
(\mathrm{n}=12)\end{array}$ & $3(25 \%)$ & $11(92 \%)$ & 3,16 & $4(33 \%)$ & $8(66 \%)$ & $5(42 \%)$ \\
\hline
\end{tabular}

SDE = stapedectomia; SDO = stapedotomia

csoport között nem volt szignifikáns különbség a posztoperatív első napon történő önálló közlekedés tekintetében (OR: 0,25; CI: 0,05-1,37) (8. kérdés).

A mútétet követő második napon fellépő szédüléses panaszok tekintetében a két mütéttípus között nem találtunk szignifikáns különbséget (OR: 2,00; CI: 0,3810,41) (9. kérdés). Az SDO-n átesett betegek esetében a második posztoperatív napon jelzett szédülés erősségének átlaga 1,416 volt, míg az SDE-n átesett betegek esetében 2,083. Ez jelentős csökkenés az előző napi 3,16 átlaghoz képest (11. kérdés). Az önállóan közlekedni tudó betegek arányában nem mutatkozott szignifikáns különbség a két csoport között (13. kérdés; OR: 0,24; CI: 0,04-1,36).

A harmadik napon fellépő szédülés tekintetében nem találtunk szignifikáns különbséget az általunk vizsgált két csoport között (14. kérdés; OR: 5,00; CI: 0,75-33,21). A szédülés erôssége azonban a harmadik napra mindkét csoportban jelentősen mérséklődött (16. kérdés). A posztoperatív harmadik napon sem adódott szignifikánsnak a különbség a két csoport között önálló közlekedés tekintetében (18. kérdés; OR: 0,13; CI: 0,01-1,33).

Az SDO-betegcsoportban 7 beteg (58\%) legkésőbb egy hónappal a mütét után már munkába tudott állni, további 2 beteg (17\%) pedig 50 nap elteltével állt munkába. Az SDE-betegcsoportban mind a $8(67 \%)$, preoperatívan aktívan dolgozó beteg munkába állt legkésőbb a posztoperatív 40. napon (20. kérdés). Az SDO mütéti csoportba tartozó 8 , már a mütét előtt is aktív autóvezető betegből 5 -en $(62,5 \%)$ voltak képesek ismét autót vezetni a mútét után két héttel, míg az arány 9-ből 3 (33\%) beteg volt az SDE mütéti csoportban (21. kérdés).

A kérdőív kitöltésekor az SDO-betegek között egyetlen betegnek (8\%), az SDE-betegcsoportban 2 betegnek (17\%) voltak szédüléses panaszai. Szédüléses panaszok tekintetében nem volt szignifikáns különbség a vizsgált két csoport között (OR: 2,20; CI: 0,17-28,14). Az álta-

3. táblázat | Szubjektív kérdőív eredményei - II.

\begin{tabular}{llll}
\hline & $\begin{array}{l}\text { Harmadik nap } \\
\text { szédül (fó) }\end{array}$ & $\begin{array}{l}\text { Harmadik nap } \\
\text { önállóan jár (fó) }\end{array}$ & $\begin{array}{l}\text { Két hét múlva } \\
\text { vezet }(\text { fó })\end{array}$ \\
\hline SDO $(\mathrm{n}=12)$ & $2(17 \%)$ & $11(92 \%)$ & $5 / 8(62,5 \%)$ \\
$\operatorname{SDE}(\mathrm{n}=12)$ & $6(50 \%)$ & $5(42 \%)$ & $3 / 9(33 \%)$ \\
\hline
\end{tabular}

SDE $=$ stapedectomia $;$ SDO = stapedotomia lunk vizsgált 24 betegből 7 betegnek voltak preoperatív szédüléses panaszai (29\%). A kérdőív kitöltésekor már csak 3 beteg panaszkodott szédülésre (12,5\%) (27. kérdés). Az SDO-csoportban a posztoperatív 400. napon is szédüléses panaszokkal küzdő betegnek a preoperatív 3-as erôsségü szédülése 1-es erősségưre mérséklődött. Ezzel szemben az SDE-csoportban a kérdőív kitöltésekor is szédüléssel küzdő 2 beteg a mútét előtt nem számolt be ilyen panaszokról (29. kérdés).

A kiemelendő eredményeket a 2. és 3. táblázat, valamint a 4 ábra tartalmazza.

\section{A statikus poszturográfiás vizsgálat eredményei}

A stapedotomiás csoportból a késői posztoperatív vizsgálaton 7 személy jelent meg, míg a stapedectomiás csoportból 8 betegnél végeztük el a vizsgálatot. Általánosságban elmondható, hogy a preoperatív eredmények rosszabbak vagy hasonlóak voltak, mint a posztoperatívak, illetve, hogy a legmagasabb értékeket, a vártnak megfelelően, a legnehezebb helyzetben, a IV. pozícióban mértük. Mütéti típustól függetlenül nagy egyéni különbségeket regisztráltunk. Az eredmények a nagy egyéni különbségek miatt nem tekinthetők szignifikánsnak, csak trendeket mutatnak. Bemutatjuk mindhárom irányú vizsgálat (API, LRI és RTI) eredményeinek átlagát (5. és

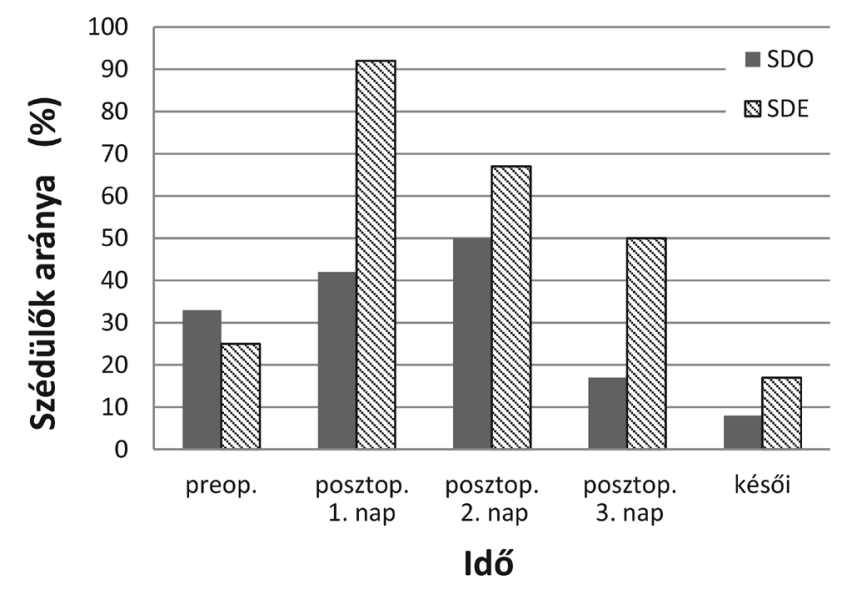

4. ábra A szédüléses betegek aránya stapedotomia, illetve stapedectomia előtt, valamint a mútétet követően 


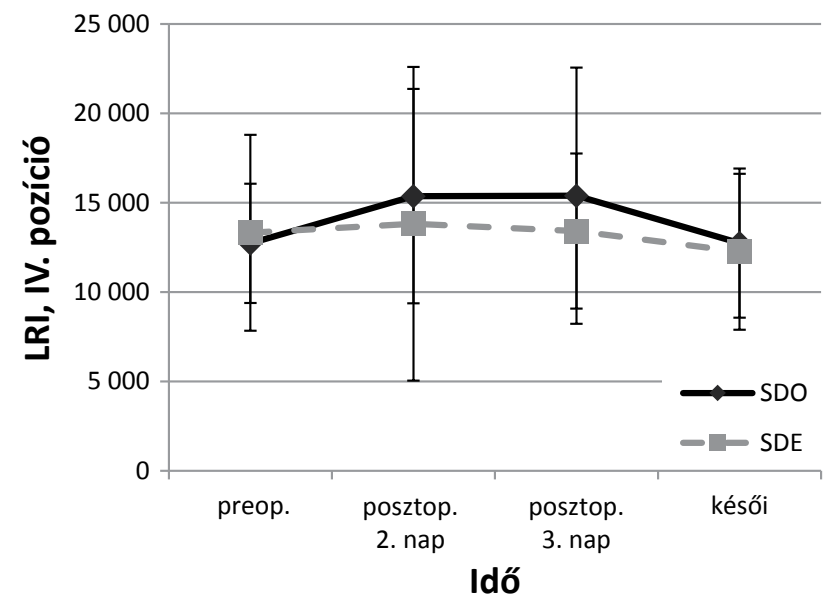

5. ábra $\quad$ Az LRI IV. pozíció összesített eredményei
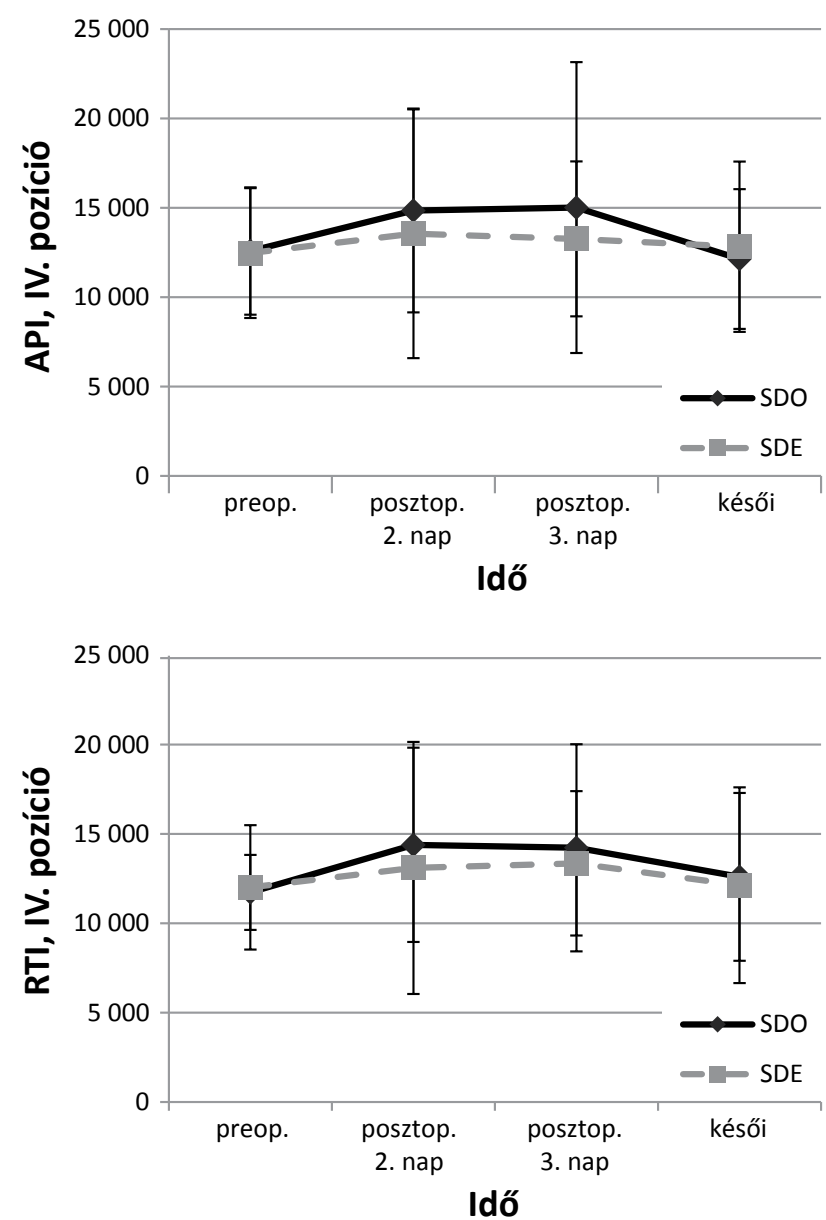

6. ábra $\quad$ Az API és az RTI IV. pozíció összesített eredményei

6. ábra), részletesebben az LRI-vizsgálat eredményeit elemezzük.

A legnehezebb, IV. pozícióban regisztráltuk mindkét betegcsoportban a legnagyobb kilengéseket mind pre-, mind posztoperatíve. Figyelemre méltó ugyanakkor, hogy a stapedectomiás betegcsoport eredményei némileg javultak, míg a stapedotomiás csoport eredményei megegyeztek a preoperatív eredményekkel, vagyis ugyanolyan stabilak betegeink, mint a mútét előtt. Az SDO-csoportban a preoperatív átlagos LRI integrált értéke (azaz a kilengés mértéke) 12725 (100\%). A posztoperatív második napon 14132 (111\%), a harmadik napon 15391 (121\%), míg 275 nappal később 12736 (100\%). Az SDE-csoportban az átlagos preoperatív érték 13317 volt, míg a posztoperatív második napon 13824 (104\%), a harmadik napon 13412 (101\%), míg a 275 . napon 12254 (92\%) volt (5. ábra).

A másik kétirányú elmozdulásból számított integrálértékek vonatkozásában az LRI-nek megfelelő tendenciák láthatóak. A korai posztoperatív vizsgálatoknál (második-harmadik nap) az SDE-csoport jobban teljesített, de a nagy szórás miatt ezek nem tekinthetóek szignifikánsnak. A késói posztoperatív eredmények átlagai gyakorlatilag megegyeznek a két csoportban (6. ábra).

\section{A retrospektio kérdōí és a poszturográfiás vizsgálat eredményeinek összehasonlitása}

Mútéti típustól függetlenül a kérdő́ív alapján az első posztoperatív napon szédülő és nem szédülő betegeket külön csoportokba soroltuk, és összevetettük a poszturográfiával nyert eredményeikkel (7. ábra). A teljesség igénye nélkül a lateralis (LRI) értékeket mutatjuk a IV. pozícióban.

Látható, hogy mútét előtt a később szédülő betegek jobb eredményt értek el. A posztoperatív második és harmadik napon, a kezdeti értékekhez képest gyengébben teljesített mindkét csoport amellett, hogy az átlagértékek között minimális különbséget lehetett kimutatni. A késôi posztoperatív vizsgálaton átlagban jobban szerepelt mindkét csoport a preoperatív eredményeikhez képest. Itt is kiemelendó a mérések nagy szórása.

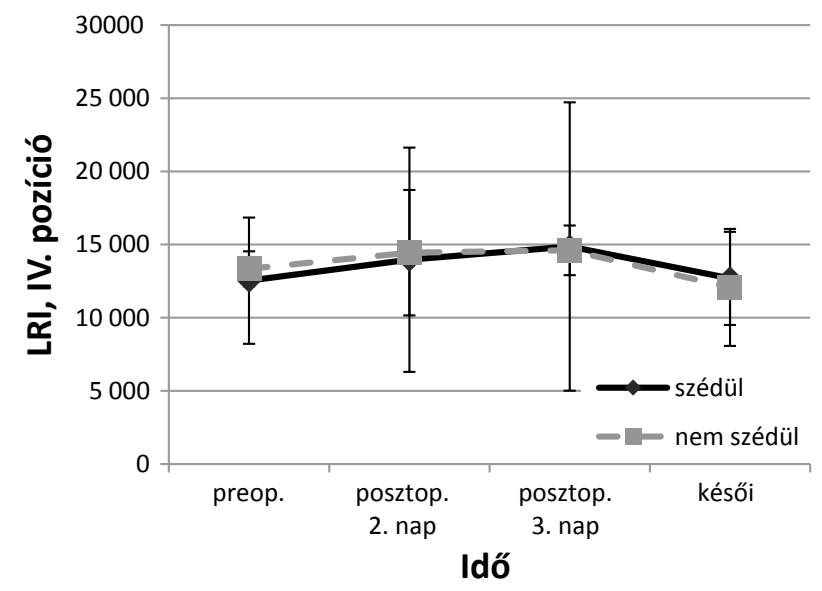

7. ábra A kérdőív alapján az első posztoperatív napon szédülő és nem szédülő betegek poszturográfiás eredményei az LRI-értékek alapján a IV. pozícióban 


\section{Megbeszélés}

A stapesmútétek lehetséges posztoperatív komplikációit Hauptman és Makishima foglalták össze: 1. a nervus facialis paresise (ritka, a legtöbbször inkomplett, szteroidkezelés mellett általában magától szúnik); 2. serosus labyrinthitis; 3 . tinnitus; 4. vezetéses halláscsökkenés kiújulása (posztoperatív első hónaptól 35 évig bármikor jelentkezhet); 5. akár süketséget elérő sensoneuralis halláscsökkenés (a legrettegettebb szövődmény, 0,5\%); 6. chorda tympani sérülése (igen gyakori szövődmény, a mütétek 30\%-ában, átmeneti szájszárazsággal, fémes ízérzettel, nyelvfájdalommal jár); 7. perilymphafistula (ritka); 8. vertigo; 9. késői vertigo (egy hónappal-hét évvel a mútét után jelentkezik) [21-25].

Özmen és mtsai 2009-es munkája szerint a betegek $82 \%$-a küzd valamilyen vestibularis tünettel a korai posztoperatív időszakban. A posztoperatív vertigo előfordulása SDO esetén 12-45\%, míg SDE esetén akár 30-69\% lehet. Szerintük a posztoperatív vertigo etiológiája sokrétü lehet: 1. a hártyás labyrinthus kompressziója, amelyben szerepe van a piston hosszának; 2 . intralabyrinther nyomásváltozások (előrehaladott otosclerosisban gyakoribb); 3. a belső fül mútéti traumája (hártyás labyrinth néha tapadhat a stapestalphoz); 4. posztoperatív perilymphafistula fennállta; 5 . labyrinthitis által okozott irritáció (megnyitás ténye); 6. csont (talpdarab) vagy vér a vestibulumban (lysosomák káros hatása) [12].

Vizsgálatunkban a kérdőívek alapján az első posztoperatív napon SDO után a betegek $42 \%$-a, SDE után 92\%-a szédült. Ez az arány a második posztoperatív napon $50 \%$, illetve $67 \%$ volt, míg a harmadik posztoperatív napon SDO után 16\%, SDE után pedig a betegek 50\%-a szédült. Százalékosan mindegyik napon a stapedotomián átesettek alacsonyabb arányban szédültek, ami megfelel az irodalmi adatoknak [12]. Poszturográfiás vizsgálatunkkal azonban nem kaptunk különbséget a két műtéttípus között, valamint a késői eredmények alapján egyik mútét sem befolyásolja hosszú távon a beteg stabilitását.

A posztoperatív vertigo vizsgálatára az irodalom több módszert is említ: computerized dynamic posturography (CDP), video-oculography (VOG), vestibular evoked myogenic potentials (VEMP), video head-impulse test (vHIT), statikus poszturográfia, a szubjektív tünetek felmérése kérdőívvel - ideális azonban nincs [1, 12-14]. Az esetlegesen elhúzódó szédülésnél felmerül a használt piston vagy columella helyzetének az ovális ablakhoz való viszonyának tisztázása. Erre a hagyományos nagy felbontású CT-vizsgálat, valamint CBCT a legalkalmasabb [26]. Vizsgálatunk során statikus poszturográfiát, valamint egy késői kérdőívet használtunk a betegek szédülésének megítélésére. Mivel klinikánkon jelenleg már elérhető a vHIT, tervezzük a jövőben az ezzel való felmérést is.
Vizsgálataink nem erősítik meg azt a feltételezést, hogy „kis lyuk - enyhe szédülés”, „nagy lyuk - erőteljes szédülés", tehát a stapes talpán ejtett nyílás nagysága nem befolyásolja a posztoperatív szédülés mértékét.

\section{Következtetés}

Kérdőíves felmérésünk eredményeiből jól látható, hogy az első posztoperatív napon jelentkező szédüléses panaszok megléte és eróssége tekintetében szignifikánsan jobb eredmény érhető el stapedotomiával. A későbbi eredmények azonban már nem mutatnak szignifikáns különbséget a két csoport között. Mindkét mütéttípus után betegeink rövid időn belül ismét teljes életet élhettek.

A poszturográfiás vizsgálatokból kapott eredményekből levonható, hogy a preoperatív és a posztoperatív értékek lényegesen nem különböztek egymástól, és a különbség is csak a korai posztoperatív szakban volt jelen, amely hamar kiegyenlítődött. Emellett a két mútéti csoport között sem találtunk szignifikáns különbséget. Ugyancsak fontos, hogy a poszturográfiás értékek nagy egyéni különbségeket mutattak. Ebből arra következtethetünk, hogy a statikus poszturográfiával jellemezhető egyensúly egy igen komplex rendszer, amelyet sok tényező befolyásol. Vizsgálatunk alapján a rendszert nem változtatja meg nagymértékben a mútéti beavatkozás, az egyensúly a mútét után független attól, hogy mekkora területen nyílt meg a belső fül, amely a kétféle mútéti megoldás alapvető különbsége. Ez fontos információ betegeinknek, akik rendszerint megkérdezik, hogy menynyire befolyásolja egyensúlyukat a mütét hosszú távon.

A kérdőíves felmérés és a poszturográfia eredményeinek összehasonlítása kapcsán elmondhatjuk, hogy a poszturográfiás vizsgálatok nem támasztják alá a kérdőíves felméréssel nyert eredményeinket, azonban kis esetszámunkra való tekintettel, valamint az egyes betegek eredményeiben tapasztalt kirívó mértékű különbségek miatt, messzemenő statisztikai következtetések nem vonhatóak le.

Anyagi támogatás: A közlemény megírása, illetve a kapcsolódó kutatómunka anyagi támogatásban nem részesült.

Szerzői munkamegosztás: H. K.: A kézirat megszövegezése. T. G.: Irodalmi áttekintés, a kérdőívek feldolgozása. S. L.: A statikus poszturográfiás platform kidolgozása. N. N.: Az adatok feldolgozása. N. A.: Szakmai konzultáció. G. I.: A szöveg lektorálása. B. P.: Az adatok statisztikai értékelése, a poszturográfiás mérések kivitelezése. A kézirat végleges változatát valamennyi szerző elolvasta és jóváhagyta.

Érdekeltségek: A szerzőknek nincsenek érdekeltségeik. 


\section{Irodalom}

[1] Trivelli M, D'Ascanio L, Pappacena M, et al. Air- and bone-conducted Vestibular Evoked Myogenic Potentials (VEMPs) in otosclerosis: recordings before and after stapes surgery. Acta Otorhinolaryngol Ital. 2010; 30: 5-10.

[2] Gros A, Vatovec J, Sereg-Bahar M. Histologic changes on stapedial footplate in otosclerosis. Correlations between histologic activity and clinical findings. Otol Neurotol. 2003; 24: 43-47.

[3] Sando I, Hemenway WG, Miller DR, et al. Vestibular pathology in otosclerosis temporal bone histopathological report. Laryngoscope 1974; 84: 593-605.

[4] Paparella MM, Mancini F, Liston SL. Otosclerosis and Meniere's syndrome: diagnosis and treatment. Laryngoscope 1984; 94 : 1414-1417

[5] Crossland G, De R, Axon P. Far advanced otosclerosis and in tractable benign paroxysmal positional vertigo treated with combined cochlear implantation and posterior semicircular canal occlusion. Laryngol Otol. 2004; 118: 302-304.

[6] Hayashi H, Cureoglu S, Schachern PA, et al. Association between cupular deposits and otosclerosis. Arch Otolaryngol Head Neck Surg. 2006; 132: 1331-1334.

[7] Paparella MM, Cureoglu S, Shao W, et al. Otosclerosis and associated otopathologic conditions. Adv Otorhinolaryngol. 2007; 65: $31-44$.

[8] Yoon TH, Paparella MM, Schachern PA. Otosclerosis involving the vestibular aqueduct and Menière's disease. Otolaryngol Head Neck Surg. 1990; 103: 107-112.

[9] Ghorayeb BY, Linthicum FH Jr. Otosclerotic inner ear syndrome. Ann Otol Rhinol Laryngol. 1978; 87: 85-90.

[10] Saim L, Nadol JB Jr. Vestibular symptoms in otosclerosis - correlation of otosclerotic involvement of vestibular apparatus and Scarpa's ganglion cell count. Am J Otol. 1996; 17: 263-270.

[11] Morales-Garcia C. Cochleo-vestibular involvement in otosclerosis. Acta Otolaryngol. 1972; 73: 484-492.

[12] Özmen AÖ, Aksoy S, Özmen S, et al. Balance after stapedotomy: analysis of balance with computerized dynamic posturography. Clin Otolaryngol. 2009; 34: 212-217.

[13] Karaca S, Basut O, Demir UL, et al. Comparison of videonystagmography and audiological findings after stapedotomy; $\mathrm{CO}_{2}$ laser vs. perforator. J Int Adv Otol. 2016; 12: 152-155.

[14] Hirvonen TP, Aalto H. Immediate postoperative nystagmus and vestibular symptoms after stapes surgery. Acta Otolaryngol. 2013; 133: 842-845.

[15] Sakamoto T, Kikuta S, Kikkawa YS, et al. Differences in postoperative hearing outcomes and vertigo in patients with otosclero- sis treated with laser-assisted stapedotomy versus stapedectomy. ORL J Otorhinolaryngol Relat Spec. 2015; 77: 287-293.

[16] Persson P, Harder H, Magnuson B. Hearing results in otosclerosis surgery after partial stapedectomy, total stapedectomy and stapedotomy. Acta Otolaryngol. 1997; 117: 94-99.

[17] Sedwick JD, Louden CL, Shelton C. Stapedectomy vs. stapedotomy. Do you really need a laser? Arch Otolaryngol Head Neck Surg. 1997; 123: 177-180.

[18] Bauer M, Pytel J, Vóna I, et al. Long-term results of the use of autogenous cortical bone columellas to replace the stapes at stapedectomy. Eur Arch Otorhinolaryngol. 2011; 268: 671-675.

[19] Gerlinger I, Bakó P, Piski Z, et al. KTP laser stapedotomy with a self-crimping, thermal shape memory Nitinol piston: follow-up study reporting intermediate-term hearing. Eur Arch Otorhinolaryngol. 2014; 271: 3171-3177.

[20] Gerlinger I, Bakó P, Szanyi I, et al. Laser stapedotomy - the upto-date solution of otosclerotic stapes fixation. [Lézerstapedotomia - az otoscleroticus stapesfixatio korszerü megoldása.] Orv Hetil. 2007; 148: 2241-2247. [Hungarian]

[21] Shea JJ, Ge XX. Delayed facial palsy after stapedectomy. Otol Neurotol. 2001; 22: 465-470.

[22] Révész P, Piski Z, Burián A, et al. Delayed facial paralysis following uneventful KTP laser stapedotomy: Two case reports and a review of the literature. Case Rep Med. 2014; 2014: Article ID 971362 .

[23] Lesinski SG. Causes of conductive hearing loss after stapedectomy or stapedotomy: a prospective study of 279 consecutive surgical revisions. Otol Neurotol. 2002; 23: 281-288.

[24] Vincent R, Sperling NM, Oates L, et al. Surgical findings and long-term hearing results in 3050 stapedotomies for primary otosclerosis: a prospective study with the otology-neurotology database. Otol Neurotol. 2006; 27: 25-47.

[25] Albera R, Canale A, Lacilla M, et al. Delayed vertigo after stapes surgery. Laryngoscope 2004; 114: 860-862.

[26] Perényi Á, Bella Zs, Baráth Z, et al. Role of cone-beam comput ed tomography in diagnostic otorhinolaryngological imaging. [A cone-beam komputertomográfia alkalmazása a fül-orr-gégészeti képalkotásban.] Orv Hetil. 2016; 157: 52-58. [Hungarian]

(Harmat Kinga dr., Pécs, Munkácsy Mihály u. 2., 7621 e-mail: harmat.kinga@freemail.hu)

\section{A rendezvények és kongresszusok híranyagának leadása}

a lap megjelenése elött legalább 40 nappal lehetséges, a 6 hetes nyomdai átfutás miatt. Kérjük megrendelőink szíves megértését.

A híranyagokat a következő címre kérjük: Orvosi Hetilap titkársága: edit.budai@akademiai.hu Akadémiai Kiadó Zrt. 